\title{
Towards Better Surveillance for Coral Ecosystems in Qatar: Stakeholder Engagement in EBM Approach
}

\author{
Abdel-Samad M. Ali, Lucia Fanning, Pedro Range, Mera Alnaimi, and Radhouan Ben-Hamadou
}

\begin{abstract}
More recently, Qatar has undergone a remarkable social and economic transformation in less than a generation. Although Qataris have a historic connection to the sea, dating back to the pearl diving days in the 19th century, the marine environment requires many interventions to be managed in a sustainable manner. Given the fact that coral reefs play an important role in the coastal ecosystem in this peninsular state, principles of environment sustainability should be undertaken for this significant habitats along the Qatari shores. Local pressures and climate change are among the most important factors that have negatively affected Qatar's coral communities. Other major threats result largely from human activities.

To achieve sustainable development that preserves the Environment is a core goal especially included in all recent development regimes in Qatar. A balance between development needs and protecting the environment represents the fourth pillar of Qatar National Vision 2030. An explicit reference is also documented in the two most recently adopted strategies of development. This study introduces a good opportunity for Qatar to position itself as a regional leader in the use of environmental management systems that integrate multiple partners in guiding and conserving coral reefs as part of valuable ecosystems as a right of future generations of Qatari nationals guaranteed by the country's sustainable development agenda. It defines 4-stage engagement framework that include 9 diverse stakeholders proposed to participate in the management of coral reef ecosystems, therefore, facilitate monitoring and enforcement, enhance understanding of system dynamics, improve management capacity to respond to shocks and disturbances, and facilitate teamwork.
\end{abstract}

Index Terms-Environmental sustainability, Qatar's national vision 2030, sustainable development goals, stakeholder participation.

\section{INTRODUCTION}

\section{A. Qatar's Portfolio of Sustainable Development}

Qatar has been enjoying an unparalleled prosperity, with exceptional economic progress evident in the increasing standard of living of its people. By 2017, Qatar had advanced to 37 th out of 189 countries with Human Development Index (HDI) of 0.856 score. Human Development Index of Qatar increased from 0.754 score in 1990 to 0.856 score in 2017

Manuscript received September 19, 2019; revised February 25, 2020. This work was supported in part by the NPRP award [NPRP8-952-1-186] from the Qatar National Research Fund (a member of The Qatar Foundation) through the National Priority Research Program.

Abdel-Samad M. Ali, Pedro Range, Mera Alnaimi, and Radhouan Ben-Hamadou are with Qatar University, Qatar (e-mail: abdelsamad@qu.edu.qa, Prange@qu.edu.qa, mera.alnaimi@qu.edu.qa, benhamadou@qu.edu.qa).

Lucia Fanning is with Dalhousie University, Halifax, Nova Scotia, Canada (email: lucia.fanning@dal.ca). with average annual HDI growth of $0.47 \%$ during the period 1990-2017 [1]. Qatar's progress in each component of HDI since 1990 the commence year of Human Development Reports to 2017 the last year we have data of HDI is shown in Table 1. During this period of time (1990-2017), Qatar's life expectancy at birth increased by 3.3 years, mean years of schooling increased by 4.4 years and expected years of schooling increased by 1.6 years. Qatar's GNI per capita increased by about 57.0 percent between 1990 and 2017 .

TABLE I: QATAR's HDI TRENDS BASED ON CONSISTENT TIME SERIES DATA AND NEW GOALPOSTS

\begin{tabular}{llllll}
\hline \hline & $\begin{array}{l}\text { Life } \\
\text { expectancy } \\
\text { at birth }\end{array}$ & $\begin{array}{l}\text { Expected } \\
\text { years of } \\
\text { schooling }\end{array}$ & $\begin{array}{l}\text { Mean years } \\
\text { of } \\
\text { schooling }\end{array}$ & $\begin{array}{l}\text { GNI per } \\
\text { capita } \\
(2011 \\
\text { PPP\$) }\end{array}$ & $\begin{array}{l}\text { HDI } \\
\text { value }\end{array}$ \\
\hline 1990 & 75.0 & 11.8 & 5.4 & 74,424 & 0.754 \\
1995 & 75.7 & 13.1 & 5.9 & 77,411 & 0.784 \\
2000 & 76.3 & 12.6 & 7.9 & 108,644 & 0.810 \\
2005 & 76.8 & 13.1 & 8.8 & 99,277 & 0.831 \\
2010 & 77.3 & 12.8 & 8.4 & 114,064 & 0.825 \\
2015 & 78.0 & 13.4 & 9.8 & 117,896 & 0.854 \\
2016 & 78.2 & 13.4 & 9.8 & 118,088 & 0.855 \\
2017 & 78.3 & 13.4 & 9.8 & 116,818 & 0.856 \\
\hline \hline
\end{tabular}

Fig. 1 below shows the contribution of each component index to Qatar's HDI since 1990. Qatar has achieved higher levels of performance in the gross domestic product (GDP) and education components of the HDI relative to the average of the Gulf Cooperation Council (GCC) countries, and is on par in terms of the health component. In 2006, the GDP Index for Qatar and the GCC Countries increased sharply, exceeding the average of the five highest HDI countries, due largely to the sharp increase in oil prices. Conversely, Qatar is lagging behind the five highest HDI countries, especially in terms of the education component because of relatively low enrolments in tertiary education. It follows those significant advances in Qatar's HDI ranking will require achieving higher post-secondary enrolments, particularly of boys, who have much lower enrolment rates than girls.

Despite significant wealth in hydrocarbons in the State of Qatar has generated one of the world's highest per capita incomes, much environmental stresses have been reported [2], [3]. Given the imbalance between environmental sustainability and socio-economic one, the government's First National Development Strategy has set out a plan for 2011-2016 that balances economic growth and environmental protection. The overarching goal was a sustainable framework that assures future generations' prosperity but with a quality of life unconstrained by shortages or inherited ecological damage including coral 
reefs heritage. The Second National Strategic Plan of Qatar assures the need to achieve environmental sustainability in 2017-2022 to strike a balance between economic and social development and the preservation of the environment and natural heritage, especially as these activities are associated with increased economic and demographic growth, putting the environment and biodiversity under a severe strain. Thus, conserving and sustaining coral reefs has become inherent regime in all developmental bodies, programs, plans and activities in Qatar.

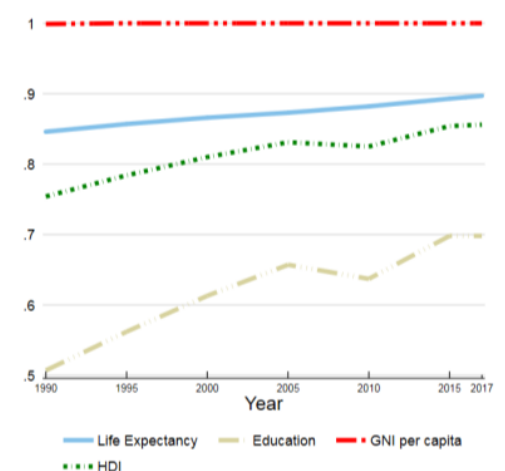

Fig. 1. Trends in Qatar's HDI component indices 1990-2017 [1].

\section{B. The Role of Marine Environment and Coral Reefs to Sustainable Development and Livelihoods in Qatar}

For the peninsula of Qatar, environmental sustainability looks to be both a goal and an enabler to achieve the aspirations of Qatar inhabitants. Undoubtedly, synergizing economic growth with social development and environmental management occupies the top priorities list in all sophisticated regimes for sustainable development in Qatar but worldwide. Qatar's marine environment is historically important and constitutes a cultural symbol and a natural source of food, water and wealth for the people of Qatar. As a peninsular country with an area of $11,437 \mathrm{~km}^{2}$, Qatar is surrounded by sea water on three sides extending for a distance of $700 \mathrm{~km}$. Qatar's territorial waters encompass some 35,000 km2 surrounding the peninsula. However, Qatar has a long history of involvement in maritime trade [4]. In addition to the mainland, Qatar includes several islands in the coastal waters of the peninsula, the most notable of which are islands of Halul (the main oil storage and exporting centre), Sharauah, Al-Bashiriya, Al-Asahat, Al-Safiliya and Al-Aliya. Coastal waters are extremely shallow, averaging 30 meter along the northern and eastern coastlines, and only 20 meter along the western coastline.

Although affected by heat stress and limited area covered by live coral, some islands and beaches in Qatar have the best reefs in the southern Arabian Gulf in terms of resource density and biological importance. Coral reefs that exists along the east and north coast represent the most biologically diverse ecological community type in Qatar, however, there is insufficient information on them. According to 2004 National Biodiversity Strategy and Action Plan, three out of Qatar's four most caught fish, are dependent at one or more life stages on coral reefs and/or seagrass beds [5]. Introducing food provisions, healthy coastal water, spawning sites, and recreational value among other services, coral reef systems as well as different marine habitats are of great value as they are pivotal in ecosystem biodiversity and stability [6]. Covering less than one percent of the Arabian Gulf floor, reefs support an estimated twenty-five percent of all marine life, with over 4,000 species of fish alone [7]. Coral reefs in Qatar support extraordinary biodiversity and are home to a multitude of different types of fish, invertebrates and sea mammals.

\section{Characteristics of Coral Ecosystems of Qatar}

A large coral community exists in the shallow waters surrounding Qatar. Qatar's eastern and northern coasts are characterized by remarkable richness and high density of coral reefs, while their western coasts lack this richness due to high salinity and temperature. Marine surveys indicate that 38 species of coral reefs have been registered, including 20 species of hard corals [8], [9]. Coral reefs can stretch 48 to 80 kilometers from the coastline, and shallow water allows light to penetrate to support photosynthetic organisms. Qatar's coral reefs are mainly concentrated on Halul Island and Umm Al-Marshan on the country's northern coast and in Khor Al-Waleed in the south. The largest and longest continuous coral areas were observed around Halul Island in Qatar [10].

The Arabian Gulf within which Qatar exists is a shallow and semi-enclosed sea with an average depth of about 35 meters, slow water exchange, high evaporation, and a harsh environment in which marine life has adapted to living in highly saline waters [11], [12]. Recent studies have indicated that these environmental conditions have not prevented marine biota, particularly coral reefs, from recovering from their initial condition after large numbers of natural disasters have been lost [13], [14]. Reefs in Halul Island are particularly characterized by their high reproductive capacity and growth to compensate for damage. This means that the waters around Qatar and the Gulf are an excellent natural laboratory to study the impact of extreme temperatures and climate change on coral reefs.

Coral reefs in Qatar grow in one of the most stressful environments for these species all over the world. Temperature variations between winter and summer are severe, varying up to over $20^{\circ} \mathrm{C}$, negatively affecting coral. In 1996, 1998 and 2002, thermal factors reduced the area covered by live coral. There has been a significant deterioration of coral reefs in Qatar and the southern Arabian Gulf in recent years. Recent global assessments classify almost all coral reefs in Qatar as at risk [15], [16].

\section{Coral Reefs as Part of the Heritage of Humanity: \\ Between International Appeals and National Policies}

Human beings live a pivotal time for coral reefs [17]. "There can be no doubt that we are at a critical tipping point, where we will either ensure or fatally compromise our ability to safeguard the world's coral reefs and the species that will support future generations of humans and countless other species," said His Royal Highness The Prince of Wales on 14 February 2018 speaking at a gathering of some of the world's leading coral reef experts and advocates in London.

Climatic impacts on coral reefs, particularly rapid increases in sea surface temperatures, may kill large areas of reefs, which will not be able to restore growth quickly enough before further events of high temperature occur. The 
UN Environment, the International Coral Reef Initiative and the UN Environment World Conservation Monitoring Centre has conducted coral reef funding analysis and reported that if greater action is not taken today, the planet could lose its live coral reefs and with them a large number of the world's marine species by 2050 [18]. According to this analysis, human being has lost at least one fifth of the world's coral reefs, with some estimates placing the loss of live coral as high as 50 per cent.

TABLE II: MAJOR NATIONAL AND INTERNATIONAL INSTRUMENTS/REGIMES RELATED TO CORAL REEFS CONSERVATION

\begin{tabular}{|c|c|c|}
\hline Instrument/Regime & $\begin{array}{l}\text { Level of } \\
\text { implementation }\end{array}$ & $\begin{array}{l}\text { Pivotal target associated with } \\
\text { coral reefs }\end{array}$ \\
\hline Aichi Target 10 & International & $\begin{array}{l}\text { By } 2015 \text {, the multiple } \\
\text { anthropogenic pressures on coral } \\
\text { reefs, and other vulnerable } \\
\text { ecosystems impacted by climate } \\
\text { change or ocean acidification are } \\
\text { minimized, so as to maintain their } \\
\text { integrity and functioning. }\end{array}$ \\
\hline SDG 14 & International & $\begin{array}{l}\text { To conserve and sustainably use } \\
\text { the oceans, seas and marine } \\
\text { resources for sustainable } \\
\text { development. }\end{array}$ \\
\hline $\begin{array}{l}\text { Global Coral Reef } \\
\text { Partnership }\end{array}$ & International & $\begin{array}{l}\text { To support countries deliver } \\
\text { internationally agreed coral reef } \\
\text { commitments through } \\
\text { ecosystem-based management of } \\
\text { coral reefs, as called for in the } \\
\text { Global Strategic Directions for the } \\
\text { Regional Seas 2013-2016. }\end{array}$ \\
\hline $\begin{array}{l}\text { The International } \\
\text { Coral Reef } \\
\text { Initiative (ICRI) }\end{array}$ & International & $\begin{array}{l}\text { An informal partnership between } \\
\text { Nations and organizations, which } \\
\text { strives to preserve coral reefs and } \\
\text { related ecosystems around the } \\
\text { world. ICRI's objectives are to: } \\
\text { Encourage the adoption of best } \\
\text { practice in sustainable }\end{array}$ \\
\hline
\end{tabular}
management of coral reefs and associated ecosystems. Build capacity. Raise awareness at all levels on the plight of coral reefs around the world.

The International International Year of the Reef

To strengthen awareness globally about the value of, and threats to, coral reefs and associated ecosystems; promote partnerships between governments, the private sector, academia and civil society on the management of coral reefs; identify and implement effective management strategies for conservation, increased resiliency and sustainable use of these ecosystems and promoting best practices; and share information on best practices in relation to sustainable coral reef management.

Paris Agreement of International According to a UN study, climate change is set to make UNESCO World Heritage coral reefs disappear by 2100 unless greenhouse gas emissions are reduced in line with the goals of the Paris Agreement on climate action. The social, cultural and economic value of coral reefs is estimated at US\$1 trillion, and unless $\mathrm{CO} 2$ emissions are drastically reduced, they will continue to be decimated at unprecedented rates, and will ultimately vanish

\begin{tabular}{|c|c|c|}
\hline $\begin{array}{l}\text { The Permanent } \\
\text { Constitution of the } \\
\text { State of Qatar }\end{array}$ & National & $\begin{array}{l}\text { The State shall preserve the } \\
\text { environment and its natural } \\
\text { balance in order to achieve } \\
\text { comprehensive and sustainable } \\
\text { development for all generations. } \\
\text { The State is obligated to take the } \\
\text { following steps: } \\
\text { - Provide a healthy environment } \\
\text { that ensures the future } \\
\text { - Address the negative impacts of } \\
\text { climate change } \\
\text { - Minimize pollution } \\
\text { - Manage environmental } \\
\text { protection } \\
\text { - Preserve natural equilibrium and } \\
\text { nurture biodiversity }\end{array}$ \\
\hline QNV 2030 & National & $\begin{array}{l}\text { The fourth pillar of QNV } 2030 \text { is } \\
\text { to achieve balance between } \\
\text { development needs and protect the } \\
\text { environment such that there is } \\
\text { harmony between economic } \\
\text { growth, social development and } \\
\text { environmental protection. It } \\
\text { confirms on Preserving and } \\
\text { protecting the environment, } \\
\text { including air, land, water and } \\
\text { biological diversity. }\end{array}$ \\
\hline NDS 2018-2022 & National & $\begin{array}{l}\text { Improve coastal and marine water } \\
\text { quality to conform with Qatar's } \\
\text { standards by } 2022\end{array}$ \\
\hline NDS 2011-2016 & National & $\begin{array}{l}\text { To sustain the environment for } \\
\text { future generations through } \\
\text { support needed analysis and } \\
\text { eventual protection of the } \\
\text { country's biodiversity, which } \\
\text { have left } 31 \text { identified species } \\
\text { vulnerable to extinction. }\end{array}$ \\
\hline
\end{tabular}

At the national level, many initiatives, policies, legislation and laws drive environmental sustainability in general and coral communities in particular. All these regimes agree that it is the time to make a concerted effort to improve dialogue between reef scientists with regional reef management and decision-makers if we are to stem the tide of decline in coral reefs in the Gulf [19], [20]. Current study responds to many international and national appeals to enhance and demonstrate ecosystem-based marine management in coral reef areas, in line with UNEP Governing Council and UNEA decisions, and as a contribution towards international targets such as Sustainable Development Goal 14 and Aichi Target 10. It is also in line with national instruments of The Permanent Constitution of the State of Qatar, Qatar's National Vision (QNV 2030), First National Development Strategy (NDS 2011-2016), and Second National Development Strategy (NDS 2018-2022). However, Table 2 refers to some important international and national calls to preserve and sustain coral reefs.

\section{StaKeHOLdER ENGAGEMENT BASED APPROACH: AN EFFECTIVE INSTRUMENT FOR CORAL REEFS MANAGEMENT IN QATAR}

A. Current Regimes for Coral Reefs Management in Qatar 
Although Qatar coral is remarkable in its ability to withstand extreme climatic conditions compared to coral in many other parts of the world, there is growing concern about the rapid pace of development that can lead to the destruction of coral in coastal and island waters in this peninsular country. For this reason, a comprehensive coral reef management plan is necessary as the main guiding principles for the enactment of laws and policies to conserve these important natural resources for the environment and marine organisms. Unfortunately, the capacity to manage coral reef ecosystems in Qatar systems is currently limited because of the lack of available data on the extent and status of coral reefs across the country. Currently, the Ministry of Municipality and Environment is the responsible authority for the management of coral reefs and all components of marine life in the State of Qatar. These natural marine systems will not be able to compensate for lost losses unless they are protected from the risks of human activities through an effective management system to manage and conserve these resources. Despite notable efforts by the Ministry, particularly in recent times, there is an urgent need for a well-defined and detailed plan in which roles, responsibilities and implementation tools are distributed and involving all relevant parties. Targeting the Ministry of Municipality and Environment when measures are proposed to protect coral reefs excluding other stakeholders either from government of private sectors will not yield the desired effective policy. It will often be most effective to involve ministries of finance or development, which have broader powers and greater access to resources. Suggested ministries to take part in the proposed policy are Development, Labour and Social Affairs; Ministry of Commerce and Industry; Ministry of Endowments and Islamic Affairs; Ministry of Culture and Sports; and Ministry of State for Energy Affairs.

\section{B. Challenges to Coral Reefs and Its Management in Qatar}

Coral reefs are among the richest environments in the earth in terms of biodiversity and ecological services they provide to different organisms, but they are among the most affected ones by natural and human factors that disturb their natural balance. The health status of coral systems has deteriorated significantly in tropical and subtropical regions of the world, including the Arabian Gulf [21]. According to recent estimates, $30 \%$ of the coral reefs in this region are at a threatened-critical stage and up to $65 \%$ of the coral reefs may have been lost already due to natural causes (fluctuation of temperatures, diseases) and anthropogenic stresses (oil pollution, unmanaged coastal development, unregulated commercial and recreational fishing and diving [22].

Marine environment in Qatar is exposed to multiple sources of drainage, including hot cooling water flowing from industrial zones which in some drains exceeds 1 million $\mathrm{m} 3 / \mathrm{h}$, brine from power and desalination plants which is almost twice the salinity of seawater, and drainage of groundwater/surface water and rainwater on the Doha Corniche through four main drains that drain nearly 75.5 million m3/year according to 2015 data, in addition to 13 rainwater sub-drains [23].

As many places worldwide, coral reefs in Qatar face both environmental challenges and human source ones. The 1960s witnessed the beginning of the decline of coral reefs in Qatar and accelerated in subsequent decades. The cold winter storm that Qatar experienced in 1964 led to unusual mass coral bleaching throughout Qatar [24]. Rising water temperatures as well as water salinity are the most influential challenges attributed to climate change. Coral reefs are vulnerable to thermal stress and recent increases in seawater temperature. The expected temperature increases will exceed coral's physiological limits and result in more frequent coral bleaching events, on par with extreme bleaching most recently witnessed. The rise of sea level will limit the light that reaches deep lying coral reefs, which will no longer be capable of sustaining growth. However, global climate change is causing interruption for ecosystems that have already been extremely disturbed and altered by over-exploitation. For example, emissions of anthropogenic greenhouse gases dissolve in the oceans, changing the acidity of the oceans. Changes in nutrient levels and temperature may also affect species composition of phytoplankton groups, which can have serious repercussions for the rest of the marine environment. Unabated ocean acidification reduces the ability of marine organisms such as corals to build their skeletons, which in turn affects the reef topography that is home to local fish populations.

Human activities are the origins of the major threats to the health, productivity and biodiversity of the marine environment. Hence, it is true that humans are at risk of being mistaken for the importance of Qatar's marine environment. It is clear that the community and institutions responsible for decision-making affecting marine biodiversity and resources are not assessing marine environments as required. This is largely due to a lack of awareness, knowledge and understanding of the benefits that marine resources provide in maintaining food chains and ecosystems.

Among human hazards are land-based activities that lead to pollutants and nutrients run into coastal waters and degradation, alteration or removal of natural habitats. In addition, land-use change and habitat loss as a result of human activities also have negative impacts on marine biodiversity. For example, the expansion of coastal agriculture has disrupted marine ecosystems in these areas. Moreover, the rapid growth of industrial scale aquaculture in many regions also brings a similar set of threats to the marine environment. Coral reefs are particularly vulnerable to such harmful pollutants and human activity as destructive fishing and tourism.

The early 1970s witnessed the beginning of the oil boom in Qatar, which in turn led to many excavations, construction and industrial expansion on an unprecedented scale. Of course, these human actions have led to a significant deterioration in coral communities in Qatar, particularly around the capital, Doha [25]. However, management of ecosystem occupies the top human source challenges in addition to socio-economic and cultural forces.

Although many studies and research over the past two decades have supported the involvement of stakeholders into coral reef management strategies, some challenges may arise from such involvement. Among potential challenges for engaging different stakeholders is the difficulty of balancing conflicting priorities and needs that may exist [26]. However, 
this challenge can be overcome and thus prevent the marginalization of any groups by introducing the principle of different priorities and needs early in the planning process. Constraints also include a lack of data on key processes within the ecosystem in addition to assumption of such engagement as ecologically risky or a threat to existing management systems.

\section{AdDRESSING THE CHALLENGES OF CORAL REEFS MANAGEMENT IN QATAR}

\section{A. Responses to Major Challenges Facing Reefs Management}

The trespass of human activities on marine environments in Qatar provides a strong argument for decisive action to ensure adherence to the principles of sustainable development. The need to develop management plan to protect and conserve the country's marine environment particularly coral reefs is well recognized by Qatar National Vision 2030. The permanent constitution of Qatar as well as all development instruments have remarkably noted the need to address and halt the degradation of coastal and marine ecosystems to ensure greater food security and reduce the health impacts and sustainable livelihoods of present and future generations.

Major responses that the State can apply in the management and conservation of Qatar's marine environment in general and coral reefs in particular are summarized in two types of responses: operational and specific. These responses are based on the framework proposed by UNEP to regulate the interaction between marine environments and human activity [27]. It is important to take into account operational responses to all policy options while specific responses relate to sectors.

Operational responses, referred to as mechanisms to correct the foundations for stakeholder participation in environmental decision-making on coral reefs, include capacity development, as well as communication, education and public awareness of the importance of these sources of biodiversity and their important value to the lives of all inhabitants of Qatar.

Specific responses referred to as building blocks of sustainable development include components of national maritime policy, integrated marine and spatial planning, coastal and marine ecosystem survey and mapping, sustainable fisheries, marine aquaculture, marine reserves and restoration, public-private partnership, cooperation Regional and International.

If there is a sincere intention to preserve the remaining coral ecosystems in the State of Qatar, and to preserve this important advantage for future generations, the need for rapid but calculated intervention in the management of marine ecosystems in general and coral communities in particular is clearly needed. Other suggested solutions in Qatar include establishing a uniform nationwide carbon tax framework to promote environmentally conscious behavior; and ways of enacting localized polices that deal with the development of hydrocarbon resources to tackle climate change. It is also imperative that a comprehensive, detailed database on the status and location of coral reefs across the country be initiated immediately. In addition, it is necessary to establish a national coral baseline survey and monitoring network to guide the proactive management of environmental resources in Qatar. Thus, it is clear that Qatar needs a systematic plan for coral reef management that includes: A) Implement long-term partnerships for monitoring, management and conservation of coral reef sites; B) Promote and coordinate local and regional conventions on coral reef issues; $C$ ) Building national capacity for coral reef conservation; D) Promote awareness and education on coral reef conservation; E) Encourage applied research to support management decisions; F) Periodic monitoring of coral reef ecosystems for sustainable use; and G) Manage, maintain and disseminate coral reef data.

\section{B. Employing the Stakeholder Engagement Based Approach for Coral Reefs Management in Qatar}

To assure the survival of coral reefs in Qatar depends on the success of a management system that encompasses all stakeholders in place across the country. The need for stakeholder participation in environmental decision-making and its integration into national and international policy is increasingly sought [28]-[30]. Environmental management of coral communities requires various stakeholder participation, which is essential to facilitate feedback, social learning and teamwork needed to respond to disturbances and change that may occur. Effective multi-stakeholder participation in ecosystem management is proposed to improve the system's ability to detect and identify shocks and disturbances, facilitate monitoring and implementation, and enhance understanding of system dynamics.

The present study focuses in particular on the involvement of stakeholders in environmental decision-making on coral reefs as the most important of these responses, according to many recent sources and studies. To address the challenges that face coral reefs' management in Qatar, it is necessary to manipulate the negative effects of sectorial development programs of coastal ecosystems that has been adopted long time ago. Reviewing different literatures and empirical studies coupled with experiences from developed nations suggest employing ecosystem-based management (EBM) approach as an effective solution for such challenges [31], [32]. As stated by the Communications Partnership for Science and the Sea (COMPASS), ecosystem-based management (EBM) is 'an integrated approach to management that considers the entire ecosystem, including humans. The goal of EBM is to maintain an ecosystem in a healthy, productive and resilient condition so that it can provide the services humans want and need. EBM differs from current approaches that usually focus on a single species, sector or activity or concern; it considers the cumulative impacts of different sectors. Accordingly, EBM looks to be an effective regime to overcome major challenges facing reefs management since it is primarily based on understanding and managing how humanity interacts with the environment in question and how this could potentially influence the ecosystem and thus management should focus on minimizing these impacts. Fig. 3 defines the features of the proposed EBM the interaction triangle, which describes 
the relationship between varied stakeholders (actors) in the EBM developmental process [33], [34].

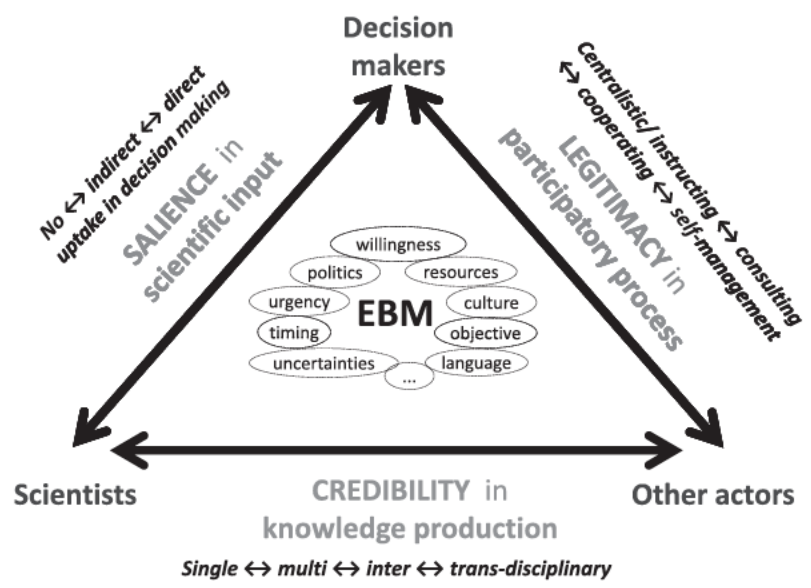

Fig. 3. The EBM triangle of interaction, specifying an interaction spectrum (outside, black) for each of the three dimensions (grey). Encircled inside the triangle, examples of context specific factors [33].

Consistent with recent studies in this area, the present study suggests more engagement of coral reefs' stakeholders to EBM [21], [35]. The proposed stakeholder engagement based approach adopts the following regimes to reduce and manage local-scale threats of coral reefs: long and short-term strategic planning; cooperation between government, research centers, NGOs, and other stakeholders; implementing local policy and regulations; community action to reduce and manage local threats; increased local awareness; governmental commitment; and resourcing of sufficient local response to the threat that climate change poses to coral reefs.

As part of its National Priority Research Program (NPRP8-952-1-186), the Qatar National Research Foundation funded a three-year project focusing on two national marine ecosystems, coral reefs and seagrass beds. Expected outcomes of this project will be used to investigate the potential benefit of stakeholder participation in EBM for coral reefs in Qatar. The project aims mainly to achieve the following four objectives: 1 . To understand the social component of coral reef and seagrass bed ecosystems by soliciting management objectives and goals for these resources from key Qatari stakeholders, including government agencies; 2 . To characterize coral reef and sea grass communities, their health, associated biodiversity and ecosystem functioning; 3 . To evaluate the ecosystem services provided by coral reefs and seagrasses to Qatar; and 4. To develop and share with key decision makers and key stakeholders a process for enhancing ecosystem based management strategies that contribute to the sustainability of these two coastal ecosystems.
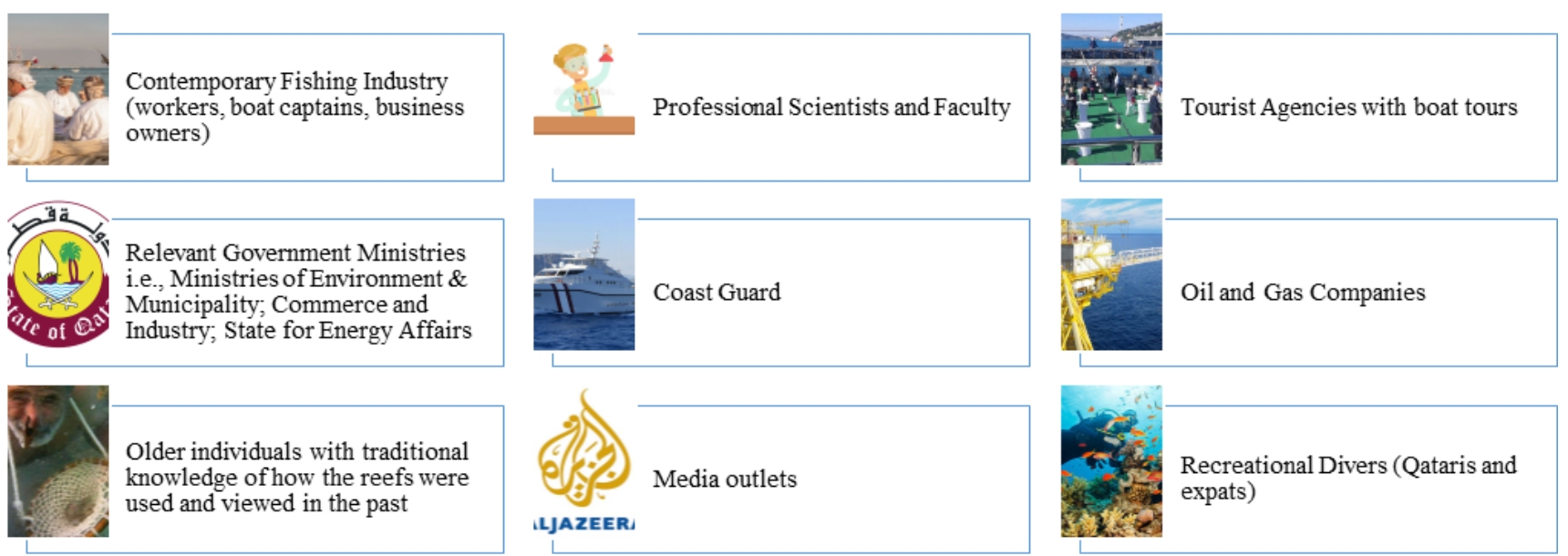

Fig. 4. Diverse stakeholders in EBM for Qatar's coral reefs.

This particular project is focused on research and creating awareness rather than any physical construction or altering of the landscape or environment. Thus, the primary stakeholders would be those who in some way interact with the coral reefs or have an impact on these reefs, but since the reefs are part of Qatar's natural heritage, there is a sense in which the entire Qatari population is potentially relevant for preservation of the endangered coral reefs. Thus, in this project, the focus will be on interviews with the variety of stakeholders and compiling the views expressed rather than designing a specific group meeting that would include the full range of stakeholders.

The variety of stakeholders for Project NPRP8-952-1-186 is larger and more diffuse than most projects. The focus on the ecosystem relating to management of Qatar's coral fields does not involve a specific location on land, since the coral reefs are located offshore, but involves all individuals, businesses and government agencies that have a relation to these reefs. Fig. 4 identifies key groups of stakeholders, some of which may overlap. In many cases, the active and wide participation of stakeholders in decision-making has proven to improve the recovery of coastal ecosystems, especially coral communities. This process is necessary to promote ownership of policies, strategies and programs transferred with a view to the conservation and sustainable development of reefs.

Proposed steps and detailed activities to involve diverse stakeholders in EBM for Qatar's coral reefs are defined in the four Stage Engagement Framework illustrated in Fig. 5.

The engagement of the nine mentioned stakeholders in the EBM for Qatar reefs will definitely contribute to developing research capabilities and reputation of local expertise and institutions and making Qatar leading the regional efforts in marine sciences. In addition, it is expected to provide 
regulatory national bodies with accurate status of the health of these ecosystems. Moreover, it may provide socioeconomic insight about societal goals by the use of coral reefs ecosystems in Qatar.

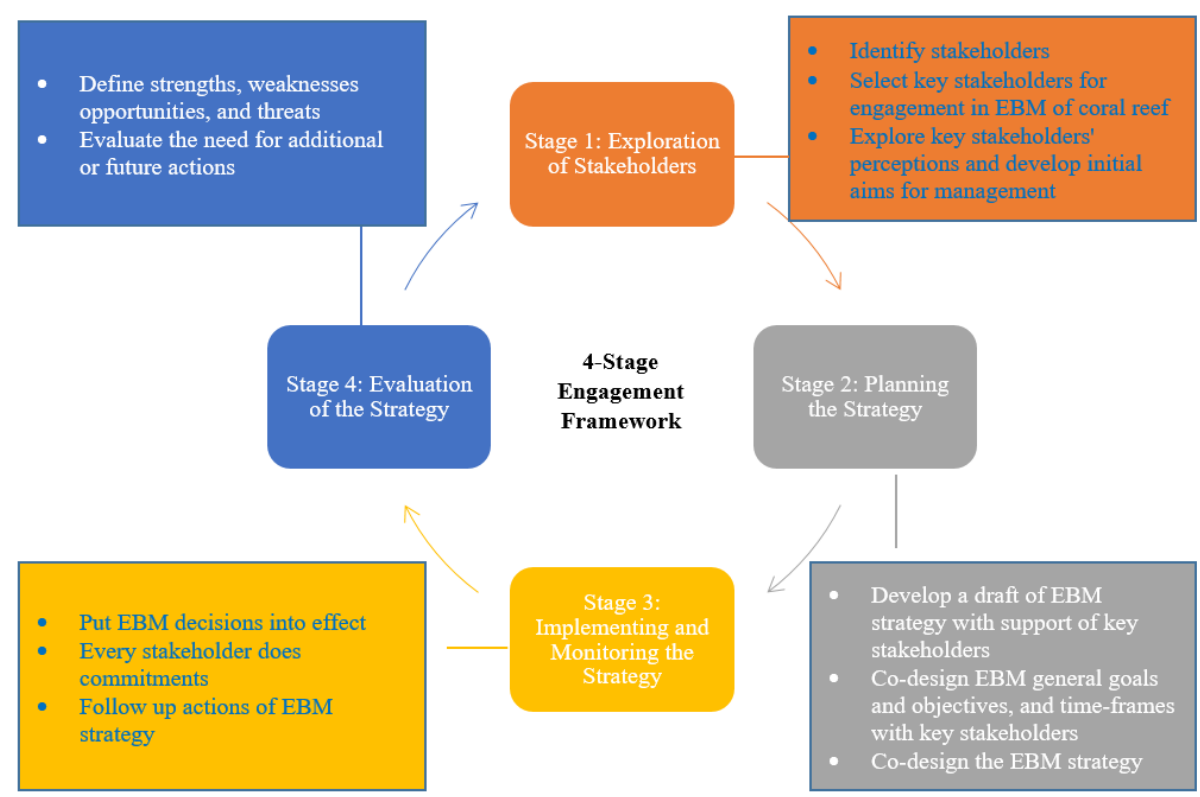

Fig. 5. Four-stage framework to engage stakeholders in EBM for Qatar's coral reefs.

\section{CONCLUSION}

All development instruments in Qatar assure that a healthy interconnection between land and marine environments is crucial to achieving Qatar's sustainable development aspirations. Current study build upon this argument coupled with the Sustainable Development Goal 14 of the UN 2030 Agenda, which provides for the conservation of at least $10 \%$ of coastal and marine areas, should make the ratio higher for coral reefs, bearing in mind that $70 \%$ of coral reefs are under threat. Coral reefs in Qatar plays significant ecological, economic, tourism and cultural roles, but are rapidly deteriorating as a result of rising temperatures and coastal development, which are key reasons for increasing the risks to such critical environments. Consultations among all stakeholders of Qatari society, including civil society and the private sector, Qatar's National Development Strategy takes into account different needs of future generations in addition to cultural and religious values, covering all aspects of social, economic and environmental activity. The study identifies a four-stage engagement framework involving nine different stakeholders proposed to participate in the management of coral reef ecosystems, thereby facilitating monitoring and enforcement, enhancing understanding of system dynamics, improving management capacity to respond to shocks and disturbances. The proposed stakeholder engagement- based model will support Qatar to be a model nation of healthy coral reefs that provide habitat for fisheries, income as appealing environments for tourism, food and protection for coastal sites and beaches.

\section{CONFLICT OF INTEREST}

The authors declare no conflict of interest.

\section{AUTHORS CONTRIBUTION}

The first author created the research plan and took the lead in writing the manuscript and its submission to the journal The second author suggested the methodology. The third, fourth and fifth authors participated in the empirical study.

\section{ACKNOWLEDGMENT}

This publication was made possible by the NPRP award [NPRP8-952-1-186] from the Qatar National Research Fund (a member of The Qatar Foundation) through the National Priority Research Program. The statements made herein are solely the responsibility of the authors.

\section{REFERENCES}

[1] Human Development Indices and Indicators: 2018 Statistical Update, UNDP, 2018.

[2] C. Lanouar, A. Y. Al-Malk, and K. Al Korbi, "Is it possible to improve environmental quality without reducing economic growth: Evidence from the Qatar economy?" Renewable and Sustainable Energy Reviews, vol. 82, pp. 25-39, 2018.

[3] H. M. Hassan, A. B. Castillo, O. Yigiterhan, E. A. Elobaid, A Al-Obaidly, E. Al-Ansari, and J. P. Obbard, "Baseline concentrations and distributions of Polycyclic Aromatic Hydrocarbons in surface sediments from the Qatar marine environment," Marine Pollution Bulletin, vol. 126, pp. 58-62, 2018.

[4] R. Carter, "Boat remains and maritime trade in the Persian Gulf during the sixth and fifth millennia BC," Antiquity, vol. 80, no. 307, pp. 52-63, 2006.

[5] Qatar National Biodiversity Strategy and Action Plan Assessment, Biodiversity Inventory, Final Report, Ministry of the Environment, 2004.

[6] A. Eladawy, K. Nadaoka, A. Negm, O. C. Saavedra, and M. Hanafy, "Assessment of long term thermal stress on Egyptian coral reefs based on remotely sensed sea surface temperature data," International Journal of Environmental Science and Development, vol. 6, no. 12, pp 938-946, 2015.

[7] L. Burke, K. A. Reytar, M. A. Spalding, and A. L. Perry, Reefs at Risk, World Resources Institute, Washington, DC., 2011.

[8] M. A. Abdel-Moati, "Coral reef conservation in Qatar," SCENR SCENR-State of Qatar, 2004

[9] H. Rezai, S. Wilson, M. Claereboudt, and B. Riegl, "Coral reef status in the ROPME sea area: Arabian/Persian Gulf, Gulf of Oman and Arabian Sea," Status of Coral Reefs of the World, vol. 1, pp. 155-170, 2004.

[10] B. M. Riegl and S. J. Purkis, "Coral reefs of the Gulf: Adaptation to climatic extremes in the world's hottest sea," Coral reefs of the Gulf, pp. 1-4, Springer, Dordrecht, 2012. 
[11] A. Hashim and M. Hajjaj, "Impact of desalination plants fluid effluents on the integrity of seawater, with the Arabian Gulf in perspective," Desalination, vol. 182, no. 1-3, pp. 373-393, 2005.

[12] M. L. Richlen, S. L. Morton, E. A. Jamali, A. Rajan, and D. M. Anderson, "The catastrophic 2008-2009 red tide in the Arabian Gulf region, with observations on the identification and phylogeny of the fish-killing dinoflagellate Cochlodinium polykrikoides," Harmful algae, vol. 9, no. 2, pp. 163-172, 2010.

[13] S. I. M. O. N. Wilson, S. M. Reza, F., M. Reza, and M. I. C. H. E. L. Claereboudt, "Status of coral reefs of the Persian/Arabian Gulf and Arabian Sea region," Status of Coral Reefs of the World 2002, pp. 53-62, 2002.

[14] A. C. Baker, C. J. Starger, T. R. McClanahan, and P. W. Glynn, "Coral reefs: corals' adaptive response to climate change," Nature vol. 430, no. 7001, p. 741, 2004.

[15] L. Burke, K. Reytar, M. Spalding, and A. Perry, Reefs at Risk Revisited, World Resources Institute, The Nature Conservancy, World Fish Center, International Coral Reef Action Network, UNEP World Conservation Monitoring Centre and Global Coral Reef Monitoring Network: Washington, DC 114, 2011.

[16] J. A. Burt, E. G. Smith, C. Warren, and J. Dupont, "An assessment of Qatar's coral communities in a regional context," Marine Pollution Bulletin, vol. 105, no. 2, pp. 473-479, 2016.

[17] J. A., Burt, E. G. Smith, C. Warren, and J. Dupont, "An assessment of Qatar's coral communities in a regional context," Marine Pollution Bulletin, vol. 105, no. 2, pp.473-479, 2016.

[18] O. Hoegh-Guldberg, E. V. Kennedy, H. L. Beyer, C. McClennen, and H. P. Possingham, "Securing a long-term future for coral reefs," Trends in Ecology \& Evolution, vol. 29, October, 2018.

[19] M. El Raey, "Impact of sea level rise on the Arab Region," Arab Climate Initiative/UNDP, 2010

[20] J. A. Burt, "The growth of coral reef science in the Gulf: A historical perspective," Marine Pollution Bulletin, vol. 72, no. 2, pp. 289-301, 2013.

[21] T. R. McClanahan, N. A.J. Graham, M. A. MacNeil, N. A. Muthiga, J. E. Cinner, J. H. Bruggemann, and S. K. Wilson, "Critical thresholds and tangible targets for ecosystem-based management of coral reef fisheries," in Proc. the National Academy of Sciences, vol. 108, no. 41, pp. 17230-17233, 2011.

[22] A. A. Monroe, M. Ziegler, A. Roik, T. Röthig, R. S. Hardenstine, M. A. Emms, T. Jensen, C. R. Voolstra, and M. L. Berumen, "In situ observations of coral bleaching in the central Saudi Arabian Red Sea during the 2015/2016 global coral bleaching event," PLoS One, vol. 13 , no. 4, e0195814, 2018.

[23] I. Al-Qaradawi, M. Abdel-Moati, M.A.A. Al-Yafei, E. Al-Ansari, I. Al-Maslamani, E. Holm, I. Al-Shaikh, A. Mauring, P.V. Pinto, D. Abdulmalik, and A. Amir, "Radioactivity levels in the marine environment along the Exclusive Economic Zone (EEZ) of Qatar," Marine Pollution Bulletin, vol. 90, no. 1-2, pp.323-329, 2015.

[24] E. A. Shinn, "Coral reef recovery in Florida and the Persian Gulf," Environmental Geology, vol. 1, no. 4, p. 241, 1976.

[25] C. Sheppard, M. Al-Husiani, F. Al-Jamali, F. Al-Yamani, R. Baldwin, J. Bishop, F. Benzoni, E. Dutrieux, N. K. Dulvy, S. R. V. Durvasula, and D. A. Jones, "The Gulf: A young sea in decline," Marine Pollution Bulletin, vol. 60, no. 1, pp. 13-38, 2010.

[26] C. J. Walters, "Is adaptive management helping to solve fisheries problems?" AMBIO: A Journal of the Human Environment, vol. 36, no. 4, pp. 304-308, 2007.

[27] Marine and Coastal Ecosystems and Human Wellbeing: A Synthesis Report Based on the Findings of the Millennium Ecosystem Assessment, UNEP, 2006.
[28] A. M. Ali, "Targeting the poorest in developing countries: Components of multidimensional deprivation in Luxor, Egypt," International Journal of Sustainable Development \& World Ecology, vol. 20, no. 6, pp. 504-511, October, 2013.

[29] M. S. Reed, "Stakeholder participation for environmental management: a literature review," Biological Conservation, vol. 141, no. 10 pp. 2417-2431, 2008.

[30] R, Biggs, M. Schlüter, D. Biggs, E. L. Bohensky, S. BurnSilver, G. Cundill, V. Dakos, T. M. Daw, L. S. Evans, K. Kotschy, and A. M. Leitc, "Toward principles for enhancing the resilience of ecosystem services," Annual Review of Environment and Resources, vol. 37, pp. 421-448, 2012.

[31] Millennium Ecosystem Assessment, "Ecosystems and human well-being," Synthesis, 2005.

[32] S. A. Levin and J. Lubchenco, "Resilience, robustness, and marine ecosystem-based management," Bioscience, vol. 58, no. 1, pp. 27-32, 2008.

[33] C. Röckmann, J. van Leeuwen, D. Goldsborough, M. Kraan, and G. Piet, "The interaction triangle as a tool for understanding stakeholder interactions in marine ecosystem based management," Marine Policy, vol. 52, 2015, pp. 155-162.

[34] M. Alnaimi, "Towards marine sustainability in Qatar: Stakeholder participation in ecosystem based management," M.Sc. Thesis, University of Surrey, U.K., 2018.

[35] E. Mcleod, K. R. Anthony, P. J. Mumby, J. Maynard, R. Beeden, N. A Graham, S. F. Heron, O. Hoegh-Guldberg, S. Jupiter, P. MacGowan, and S. Mangubhai, "The future of resilience-based management in coral reef ecosystems," Journal of Environmental Management, vol. 233, pp. 291-301, 2019.

Copyright (C) 2020 by the authors. This is an open access article distributed under the Creative Commons Attribution License which permits unrestricted use, distribution, and reproduction in any medium, provided the original work is properly cited (CC BY 4.0).

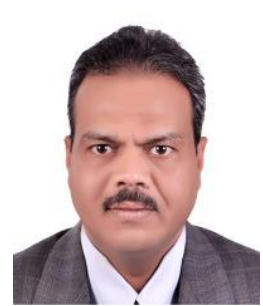

Abdel-Samad M. Ali is a professor of sociology at Qatar University. He received his $\mathrm{PhD}$ in rural sociology in 2003 through joint program between Assiut University, Egypt and the University of Tokyo, Japan. The title of his thesis is "Improving the Quality of Life in Rural Areas in Assiut Governorate: A GIS Based Approach". Before moving to Qatar University, Prof. Ali worked as a visiting associate professor at Kyoto University, Japan upon completion of Guest Researcher Position at Kyoto University sponsored by Open Society Foundation, USA. Prof. Ali has undertaken a research project entitled "Spatial Variability in Social Exclusion: GIS Based Approach" at the University of Graz, Austria in the framework of ELEMENT Programme financed by the European Commission under the Erasmus Mundus Programme. For the past 20 years, Ali has gained great opportunities to work with various teams in researching many innovative and challenging projects and to interact with many reputable researchers in Egypt, Austria, Italy, Qatar and Japan. He was a team member responsible for launching Human Development Report (HDR), sponsored by United Nations Development Programme (UNDP). Prof. Ali has broad Expertise in fields of Spatial inequality; Sociology of development; Human geography; Migration dynamics; Demography; Social inclusion in sustainable development; Participatory planning; Updating research methodologies in social sciences based on GIS; Multi-Criteria Decision Making (MCDM), Quality Assurance and Accreditation in Higher Education Institutions. 